\title{
Study on Strengthening of RC Slabs with Different Innovative Techniques
}

\author{
Tarek Alii ${ }^{1}$, Sameh Yehia ${ }^{2}$ \\ ${ }^{1}$ Faculty of Engineering at Mataria, Helwan University, Cairo, Egypt \\ ${ }^{2}$ Higher Institute of Engineering, El-Shorouk Academy, Cairo, Egypt \\ Email: dsyehia@hotmail.com
}

How to cite this paper: Ali, T. and Yehia, S. (2016) Study on Strengthening of RC Slabs with Different Innovative Techniques. Open Journal of Civil Engineering, 6, 516525.

http://dx.doi.org/10.4236/ojce.2016.64044

Received: June 11, 2016

Accepted: August 29, 2016

Published: September 2, 2016

Copyright $\odot 2016$ by authors and Scientific Research Publishing Inc. This work is licensed under the Creative Commons Attribution International License (CC BY 4.0). http://creativecommons.org/licenses/by/4.0/

\begin{abstract}
This paper presents a focused study on using different methods to enhance the ultimate capacity of flexural behavior in RC slabs. Four RC specimens were casted with common compressive strength and reinforced with steel mesh. Specimens were strengthened with different methods such as usage of GFRP sheets, carbon fibers laminate strips and near surface mounted steel rebars. All specimens were subjected to two-point loading setup. Load was increased from zero to failure load. First crack was recorded and crack pattern was observed. The behavior of strengthened specimens was compared to that of the control specimen to judge the efficiency of the used techniques. Test results showed that the used techniques were effective in enhancing the behavior of the strengthened slabs by noteworthy values.
\end{abstract}

\section{Keywords}

Slab Strengthening, GFRP Sheets, Carbon Fiber Laminate Strips, Near Surface Mounted Rebars

\section{Introduction}

There is no doubt that the problem of cracked concrete structures has become one of the most pressing problems that must join hands in efforts to reach a solution before cracks appear in structure. Some of concrete structures that were built in the past years were inadequate to carry service loads. This insufficient load carrying capacity has resulted from poor maintenance, increasing in legal load limit, insufficient reinforcement, excessive deflections, structural damages or steel corrosion, which leads to cracks. Repair, retrofitting and rehabilitation of existing concrete structures have become a large part of the construction activity; also the money spent on retrofitting of existing structures in recent years has exceeded that spent on new structures due to using traditional 
techniques [1]. The restoration, strengthening and retrofitting of concrete are work of rehabilitation/treatment adjustments to the structural elements (such as foundations, columns, beams and slabs) so that beams are recorded soundness values in strengthening and retrofitting by using FRP in the worst case of loading such as cyclic loads [2]. Enhancing the cracking loads and mode of failure of slabs as flexural elements is demanding [3] [4]. Therefore, in this research, the problem was handled and studied by testing four RC slab specimens strengthened using three different techniques to judge their effectiveness in enhancing the behavior of the strengthened slabs in addition to one pilot specimen. Nowadays, generally new techniques appear in strengthening field. One of the important structural elements is slab which is may crack due to overloading, change of building function, or fabrication errors. In this research, efficiency of slab strengthening was judged by comparing the behavior of strengthened specimens from the point of view of cracking and ultimate loads, cracking mechanism, and mode of failure. This research was focused on studying three of the most popular innovative slab strengthening techniques: GFRP sheets, carbon fiber laminate strips, and near surface mounted steel rebars.

\section{Experimental Work Program}

\subsection{Introduction}

One of these slabs was tested as reference (control) specimen. The rest three specimens were strengthened using three different techniques Glass Fiber Reinforced Polymer (GFRP) Sheets, Carbon Fiber Reinforced Polymer (CFRP) Laminate Strips and Near Surface Mounted Steel Rebars (NSMR).

\subsection{Manufacturing Procedures of Specimens}

Concrete dimensions for RC slabs are $140 \mathrm{~mm}$ thickness, $1000 \mathrm{~mm}$ length and $500 \mathrm{~mm}$ width. All slabs were reinforced with 3Y12, 6Y10 main reinforcement mesh in longitudinal and short direction, respectively, Figure 1. Specimen's forms, Figure 2 were prepared to match the proposed specimen's dimensions. Table 1 shows concrete mix de-

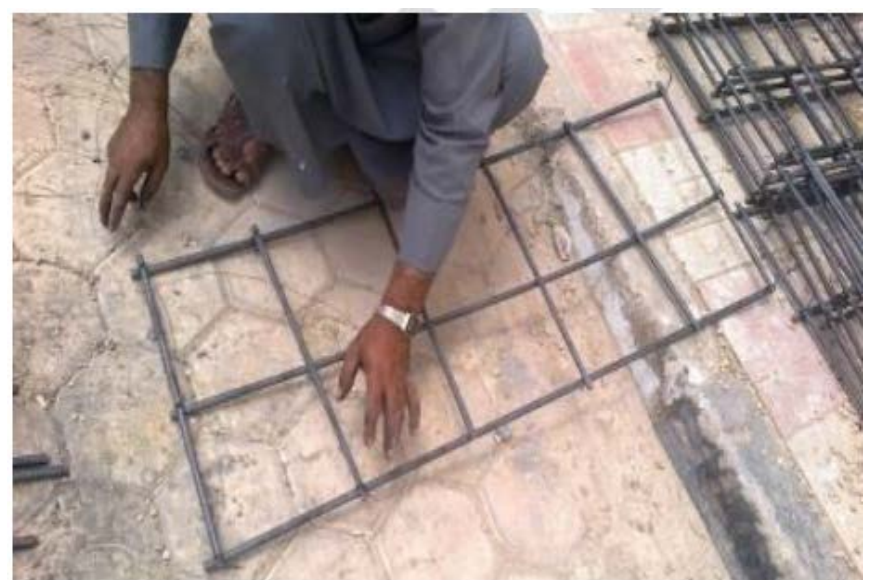

Figure 1. Slab reinforcement mesh. 


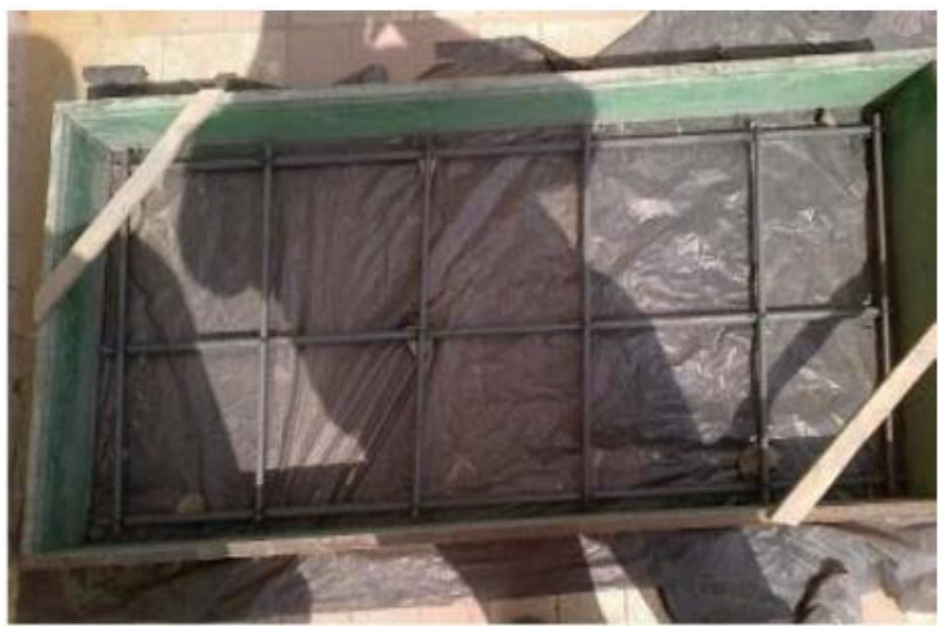

Figure 2. Specimen formwork.

Table 1. Concrete mix design proportions.

\begin{tabular}{cccc}
\hline Coarse Aggregate $\mathrm{kg} / \mathrm{m}^{3}$ & Fine Aggregate $\mathrm{kg} / \mathrm{m}^{3}$ & Cement $\mathrm{kg} / \mathrm{m}^{3}$ & Water $\mathrm{kg} / \mathrm{m}^{3}$ \\
\hline 1200 & 600 & 350 & 175 \\
\hline
\end{tabular}

sign proportions which were estimated according to British Standard [5] to obtain concrete mix with compressive strength equals $25 \mathrm{MPa}$. The mixing process of fresh concrete was made in the traditional technique using 230 liters concrete mixer. Specimens were compacted in a way to produce full compaction as much as possible by using the standard tamping rod. Finally, specimens were leveled at top to get smooth concrete surface as seen in Figure 3.

\subsection{Strengthening of Specimens}

The strengthening of RC slabs was made following the traditional procedure. Firstly, Slab surface were roughened to ensure good bond between repairing materials and concrete surface. GFRP sheets which were tailored to dimensions of $1000 \mathrm{~mm}$ length, $500 \mathrm{~mm}$ width and $1.17 \mathrm{~mm}$ thickness. Suitable resin was used to glue GFRP sheets on concrete surface. Figure 4 shows the installation procedure of GFRP sheets. The second specimen was strengthened using two carbon fiber laminate strips of dimensions 1000 $\mathrm{mm}$ length, $50 \mathrm{~mm}$ width and $1.2 \mathrm{~mm}$ thickness. Suitable epoxy adhesive was used to bond Carbon Laminates on concrete surface as shown in Figure 5. The third specimen was strengthened using two high grade steel bars with $12 \mathrm{~mm}$ diameter as near surface mounted rebars. Driller was used to engrave the positions of two bars then the main role of blower appeared to clean concrete surface before adding special adhesive epoxy to glue steel rebars. Figure 6 and Figure 7 show the installation process of the used bars in near surface mounted method. Table 2 shows the details of strengthening system used for each specimen. It should be noted that, the amount of strengthening materials was selected based on the relative cross-sectional areas and the material strengths in a way to achieve the same potential capacity. 


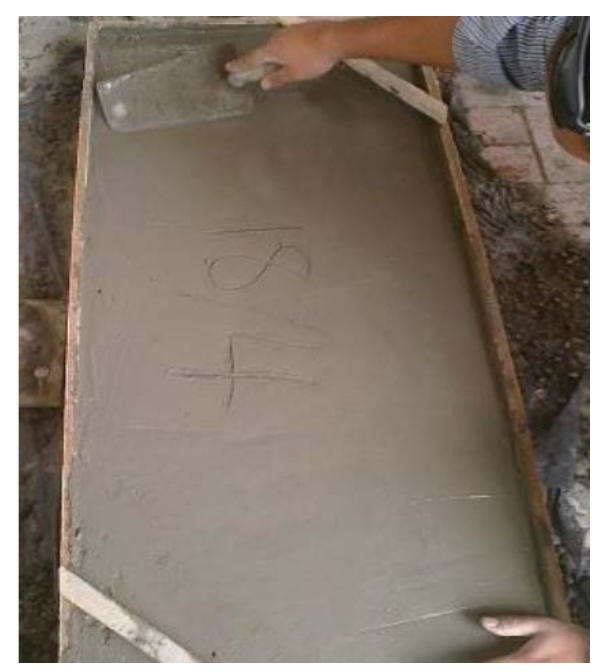

Figure 3. Final casted specimen.

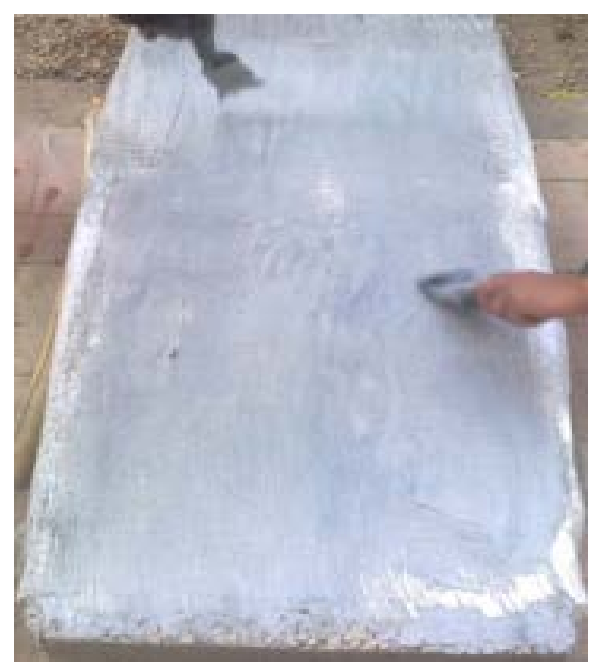

Figure 4. Installing of glass fiber sheets.

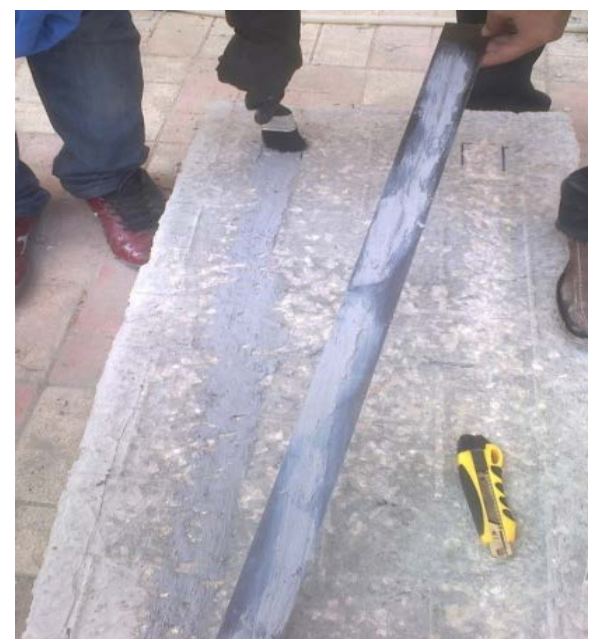

Figure 5. Installing of carbon laminate strips. 


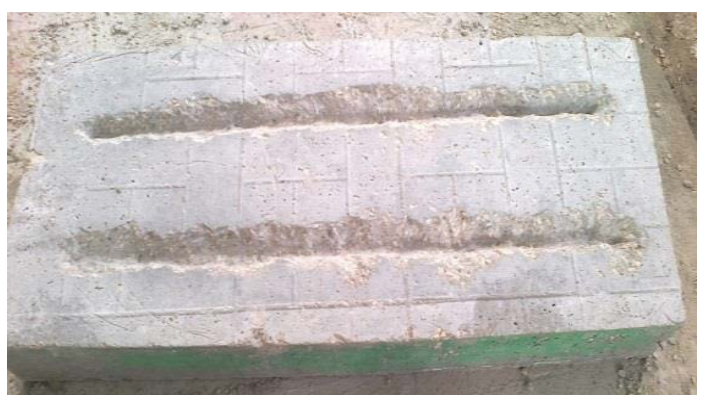

Figure 6. Drilled locations of steel rebars.

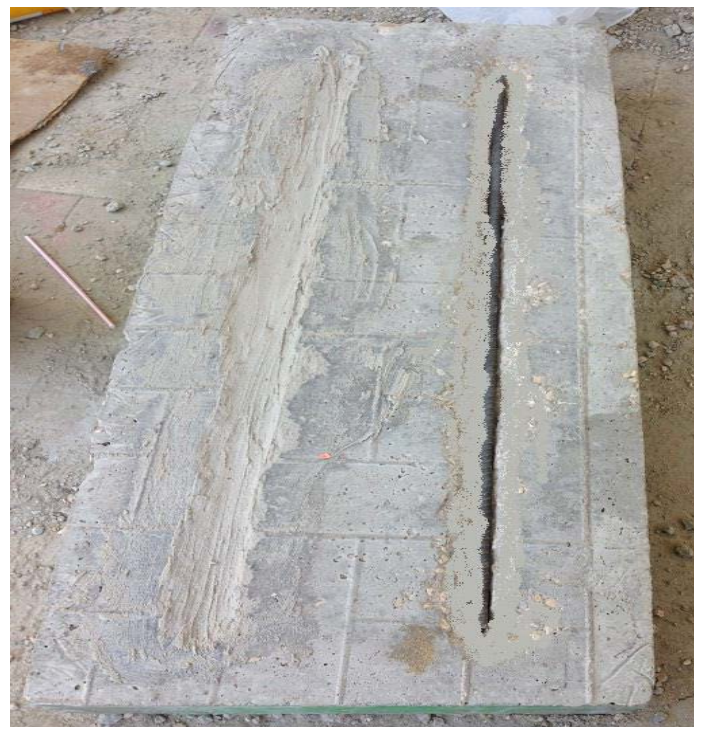

Figure 7. Embedding process of the steel rebars.

Table 2. Details of specimens.

\begin{tabular}{|c|c|c|c|c|}
\hline Specimen & $\begin{array}{l}\text { Strengthening } \\
\text { Technique }\end{array}$ & $\begin{array}{l}\text { Young's Modulus } \\
\text { of Repairing Material }\end{array}$ & $\begin{array}{c}\text { Details } \\
\text { of Strengthening } \\
\text { Element }\end{array}$ & $\begin{array}{c}\text { Added Area } \\
\text { of Strengthening } \\
\text { Element }\end{array}$ \\
\hline S1 & Control & Non & Non & Non \\
\hline S2 & GFRP Sheets & $73 \mathrm{KN} / \mathrm{mm}^{2}$ & $\begin{array}{l}\text { One sheet with } 1000 \mathrm{~mm} \\
\text { length, } 500 \mathrm{~mm} \text { width } \\
\text { and } 0.6 \mathrm{~mm}\end{array}$ & $300 \mathrm{~mm}^{2}$ \\
\hline S3 & $\begin{array}{c}\text { Carbon } \\
\text { Laminate Strips }\end{array}$ & $165 \mathrm{KN} / \mathrm{mm}^{2}$ & $\begin{array}{c}\text { Two strips } \\
\text { with } 1000 \mathrm{~mm} \text { length, } \\
50 \mathrm{~mm} \text { width and } \\
1.2 \mathrm{~mm} \text { thickness }\end{array}$ & $120 \mathrm{~mm}^{2}$ \\
\hline S4 & $\begin{array}{c}\text { Near Surface } \\
\text { Mounted Rebars }\end{array}$ & $200 \mathrm{KN} / \mathrm{mm}^{2}$ & $\begin{array}{c}\text { Two steel bars } \\
\text { with } 12 \mathrm{~mm} \text { diameter }\end{array}$ & $226 \mathrm{~mm}^{2}$ \\
\hline
\end{tabular}

\subsection{Test Setup}

RC slabs were tested under main frame with load cell capacity of $500 \mathrm{KN}$. Test specimens were tested under the effect of two-point static loads. Dial gauge was used to measure the maximum vertical deflection at middle span of slab. Load was increased 
from zero to failure load. The first crack was recorded and crack pattern was observed. Figures 8-11 show the details of test setup, instrumentation and the mode of failure of the different tested specimens.

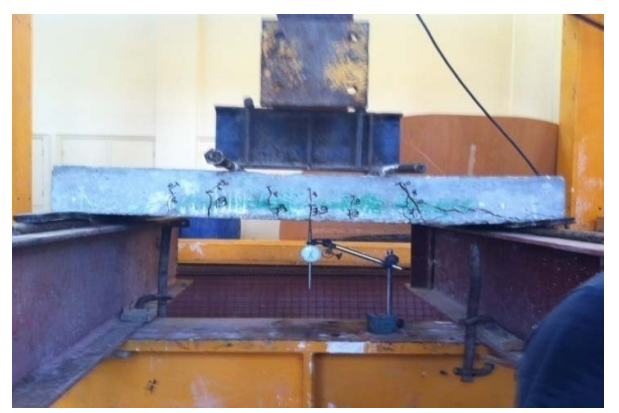

Figure 8. Test setup \& crack pattern-specimen (S1).

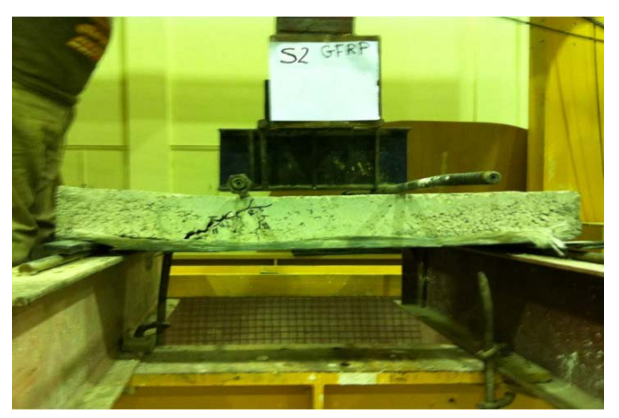

Figure 9. Test setup \& crack pattern-specimen (S2).

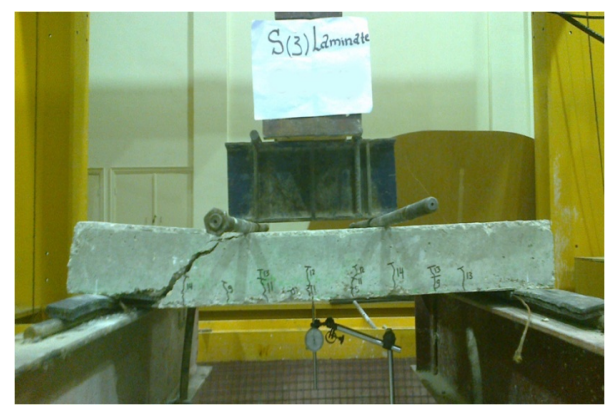

Figure 10. Test setup \& crack pattern-specimen (S3).

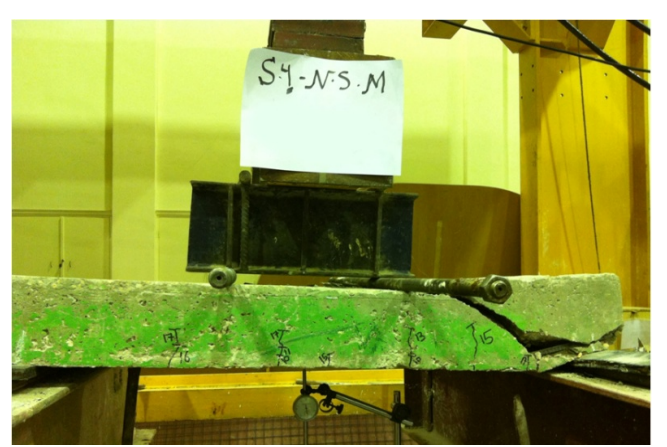

Figure 11. Test setup \& crack pattern-specimen (S4). 


\section{Analysis and Discussions of Test Results}

Test results of specimens are summarized in Table 3 and it is clear from Table 3 that the ultimate load of specimens strengthened with near surface mounted rebars, carbon Fiber laminate strips and GFRP sheets gives ultimate load higher than that for the control specimen by about $67 \%, 46 \%$ and $32 \%$, respectively. Also, firmly it was established that, the percentage of cracking to ultimate load are in the range $56 \%$ to $72 \%$. The maximum value of the (Pcr/Pult) percentage is related to specimen (S2) due to integrity of GFRP sheets to specimen with large cross-sectional area, which is, finally, leads to control cracks propagation and gained specimen more ductility in reducing cracks. The minimum value of the (Pcr/Pult) percentage respective to specimen (S4) because near surface mounted technique was made with steel reinforcements that is ductile and thus the behavior of the strengthened specimens remains ductile (under reinforced section) that is characterized by low percentage of Pcr/Pult. At the same load, deflection of specimen's recorded maximum value for specimen (S2) because of the low young's modulus of GFRP sheets compared to the other strengthening materials used. It's worth mentioning that specimens (S3) and (S4) give the best values in ultimate load capacity due to higher young's modulus of used repairing material (matrix) and the effect of high bonding of special epoxies used to concrete sofit.

Figure 12 shows the load-deflection for the tested specimens and revealed that all strengthening techniques are effective in strengthening RC slabs in this research. They increase the initial stiffness of the control specimen by about one and half folds. The used strengthening techniques do not affect the ductility or the failure mechanism of the control specimen significantly (under reinforced section); this is clear from the plateau portion of curve in the post cracking stage. It is also clear that, as unusual, using CFRP laminate strips or NSMR were not positively affecting the ductility of tested specimens, this may be attributed to the selected value of the ratio of the cross-sectional area of fibers to that of the reinforcing steel of the specimen, $A_{f} / A_{s}$ and the values of the modulus of elasticity of the used fibers.

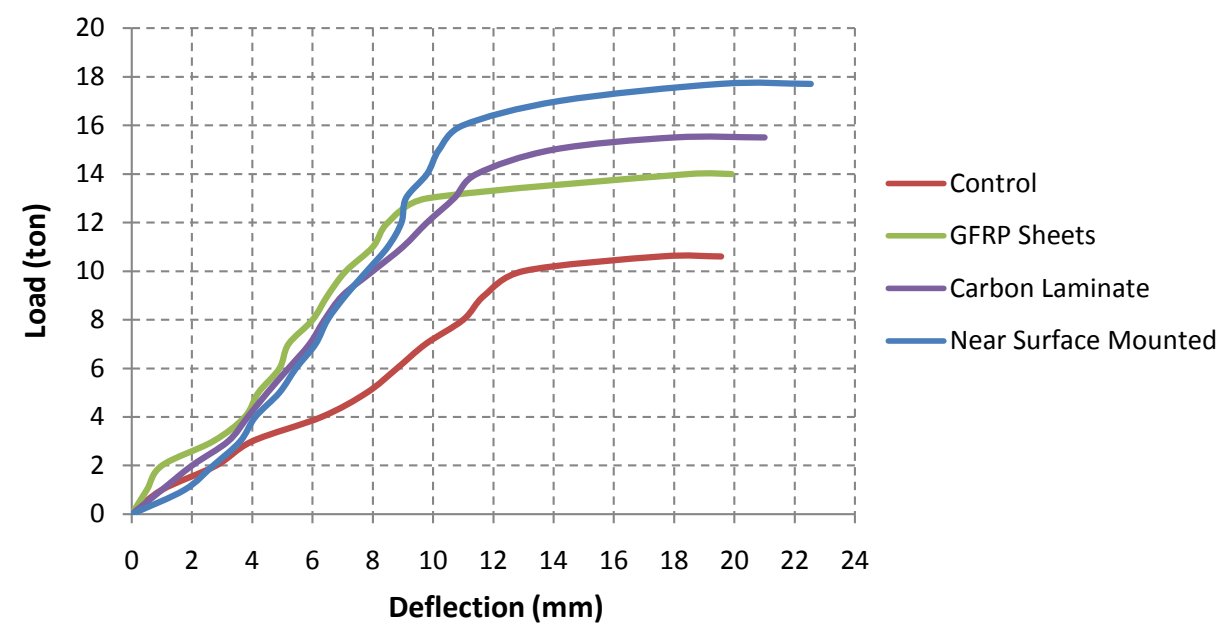

Figure 12. Relationship between load and deflection for strengthened slabs. 
Table 3. Experimental results of tested RC slabs.

\begin{tabular}{ccccccc}
\hline Specimen & Pcr (ton) & Pult (ton) & $\begin{array}{c}\text { Pcr/Pult } \\
(\%)\end{array}$ & $\begin{array}{c}\text { Displacement } \\
\text { Ductility Factor (\%) }\end{array}$ & $\begin{array}{c}\text { Max. Def. } \\
(\mathrm{mm})\end{array}$ & $\begin{array}{c}\text { Strengthening } \\
\text { Method }\end{array}$ \\
\hline S1 & 7.10 & 10.60 & $67 \%$ & $180 \%$ & 17.55 & Control \\
S2 & 10.20 & 14.00 & $72 \%$ & $260 \%$ & 18.48 & GFRP Sheets \\
S3 & 9.50 & 15.50 & $61 \%$ & $257 \%$ & 18.01 & $\begin{array}{c}\text { Carbon Laminate } \\
\text { Strips }\end{array}$ \\
S4 & 10.00 & 17.70 & $56 \%$ & $250 \%$ & 19.53 & $\begin{array}{c}\text { Near Surface } \\
\text { Mounted }\end{array}$ \\
\hline
\end{tabular}

\section{Failure Mode of Specimens}

Crack pattern of (S1) started by small bottom flexural cracks then the propagation of the cracks increased. The narrow crack with angle equal 450 appeared at the edge of tested slab cohere with small bottom flexural cracks and by increasing load, the failure took place. The failure of specimen (S2) started with little small flexure cracks followed by debonding in GFRP sheets due to increasing in load and finally failure took place. Specimen (S3) failed by excessive shallow bottom flexure cracks confirmed with deep crack with angle equal $45^{\circ}$ appeared at slab edge followed by debonding in carbon laminate strips and finally specimen failed. Sequence of crack mechanism for specimen (S4) befell by small bottom flexural cracks and deep crack with angle equal to $45^{\circ}$ appeared at slab edge. Large cracks lead to debonding of steel bars in lately state. Figure 13 shows the crack pattern for different specimens. Almost, all specimens crack pattern can be classified as flexure failure with some shear cracks.

\section{Economical Study}

The economical study helps in taking the right decision for choosing the best method to use. Table 4 was prepared with credit point system, the large number represents the optimum and vice versa (max ten points in each item). The comparison was made considering many parameters already taken in this study. In overall, carbon laminate strips method superiority on the other methods. In the first case, all studied parameters were taken into consideration and the three innovative techniques nearby the same with small variation; also the technique of GFRP sheets drooped in the first case and recorded the smallest value. If one ignores some parameters which are not significantly effective in ordinary buildings like deflection, Pcr/Pult and displacement ductility factor, carbon laminate strips technique came in the first class and can be classified as low cost to high efficiency followed by GFRP sheets/NSMR as appeared in the second case. For special structures which are subjected to earthquakes and lateral loads, the third case can represents these structures, carbon laminate strips and near surface mounted rebars methods appears as usual with their magical efficiency and performance. 

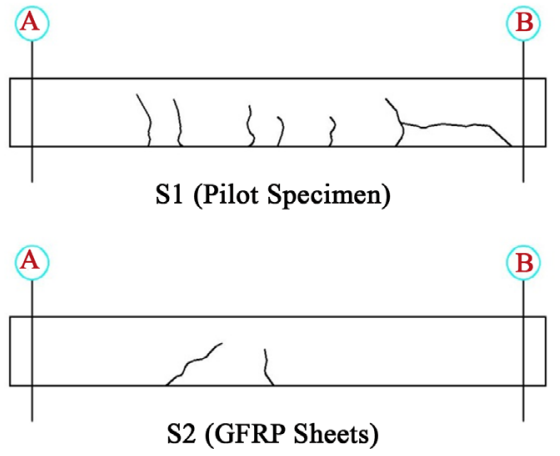

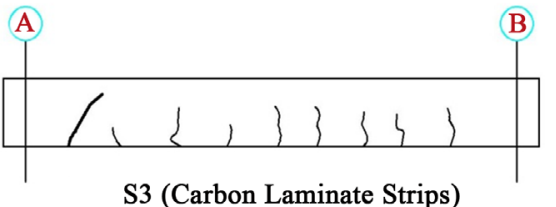

S3 (Carbon Laminate Strips)

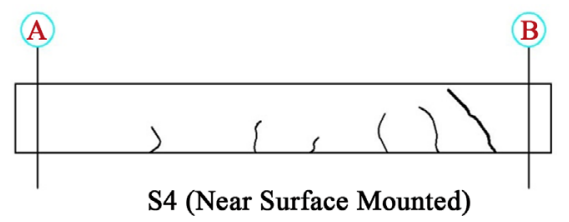

Figure 13. Crack pattern for strengthened slabs.

Table 4. Economical study to choose the suitable method to use. (a) First case; (b) Second case; (c) Third case.

(a)

\begin{tabular}{cccc}
\hline Point of Comparison & $\begin{array}{c}(\text { S2 }) \\
\text { GFRP } \\
\text { Sheets }\end{array}$ & $\begin{array}{c}(\mathrm{S} 3) \\
\text { Carbon } \\
\text { Laminate Strips }\end{array}$ & $\begin{array}{c}(\text { S4 }) \\
\text { Near Surface } \\
\text { Mounted Rebars }\end{array}$ \\
\hline Ultimate Load & 8 & 9 & 10 \\
Deflection & 9.75 & 10 & 9.2 \\
Pcr/Pult & 7.8 & 9.2 & 10 \\
Displacement Ductility Factor & 10 & 10 & 10 \\
Cost/Labor & 10 & 10 & 8 \\
Total Grade & $\mathbf{4 5 . 6}$ & $\mathbf{4 8 . 2}$ & $\mathbf{4 7 . 2}$ \\
\hline
\end{tabular}

(b)

\begin{tabular}{cccc}
\hline Point of Comparison & $\begin{array}{c}(\mathrm{S} 2) \\
\text { GFRP } \\
\text { Sheets }\end{array}$ & $\begin{array}{c}(\mathrm{S} 3) \\
\text { Carbon } \\
\text { Laminate Strips }\end{array}$ & $\begin{array}{c}(\mathrm{S} 4) \\
\text { Near Surface } \\
\text { Mounted Rebars }\end{array}$ \\
\hline Ultimate Load & 8 & 9 & 10 \\
Cost/Labor & 9.75 & 10 & 9.2 \\
Total Grade & $\mathbf{7 . 8}$ & $\mathbf{9 . 2}$ & $\mathbf{1 0}$ \\
\hline & $(\mathrm{c})$ & & $(\mathbf{S} 4)$ \\
Point of Comparison & $(\mathrm{S} 2)$ & $(\mathrm{S} 3)$ & Near Surface \\
& GFRP & Carbon & Mounted Rebars \\
\hline Ultimate Load & Sheets & Laminate Strips & 10 \\
Pcr/Pult & 8 & 9 & 10 \\
Displacement Ductility Factor & 7.8 & 9.2 & 8 \\
Cost/Labor & 10 & 10 & $\mathbf{3 8}$ \\
Total Grade & 10 & 10 & $\mathbf{3 8 . 2}$ \\
\hline
\end{tabular}

Keys of Credit Points: Ultimate Load $\equiv$ the highest $\equiv 10$; Deflection $\equiv$ the least $\equiv 10$; Pcr/Pult $\equiv$ the least $\equiv 10$; Displacement Ductility Factor $\equiv$ the highest $\equiv 10$; Cost/Labor $\equiv$ the least $\equiv 10$. 


\section{Conclusion}

Strengthening RC slabs using GFRP Sheets/CFRP Laminate Strips or using NSMR is an effective technique. Using these techniques increases the initial stiffness of the original specimens by about one and half folds and keeps the ductile behavior of the original specimens. This can be achieved by accurate selection of the percentage of the cross-sectional area of the strengthening materials to that of the reinforcing steel, $\mathrm{A}_{\mathrm{f}} / \mathrm{A}_{\mathrm{s}}$ and the selection of strengthening materials with suitable modulus of elasticity that provides approaching of compatibility conditions. Also cost study in this research facilitates directing the end-users to choose the suitable technique considering the project conditions and the governing parameters.

\section{References}

[1] Yehia, S. (2015) Behavior of Low Compressive Strength Short Columns Strengthened with External GFRP Strips/Jacket Techniques. International Journal of Technology Enhancements and Emerging Engineering Research (IJTEEE), 3, 1-5.

http://www.ijteee.org/research-paper-publishing/month/apr2015.html

[2] Ghanem, G., El-Bakey, S.A., Ali, T. and Yehia, S. (2016) Behavior of RC Beams Retrofitted/Strengthened with External Post-Tension System. International Journal of Civil, $\mathrm{Me}$ chanical and Energy Science (IJCMES), 2, 36-43.

http://ijcmes.com/issue-detail/vol-2-issue-1/

[3] Guide for the Design and Construction of Externally Bonded FRP Systems for Strengthening Concrete Structures. ACI: 440.7R-10.

[4] Bonaldo, E., Oliveira de Barros, J.A.O. and Lourenço, P.B. (2008) Efficient Strengthening Technique to Increase the Flexural Resistance of Existing RC Slabs. Journal of Composites for Construction, 12, 149-159. http://dx.doi.org/10.1061/(ASCE)1090-0268(2008)12:2(149) http://ascelibrary.org/doi/abs/10.1061/(ASCE)1090-0268(2008)12\%3A2(149)

[5] British Standard for Concrete Mix Design. BS 5328-Concrete, Part 2, Methods for Specifying Concrete Mixes.

Submit or recommend next manuscript to SCIRP and we will provide best service for you:

Accepting pre-submission inquiries through Email, Facebook, LinkedIn, Twitter, etc. A wide selection of journals (inclusive of 9 subjects, more than 200 journals)

Providing 24-hour high-quality service

User-friendly online submission system

Fair and swift peer-review system

Efficient typesetting and proofreading procedure

Display of the result of downloads and visits, as well as the number of cited articles Maximum dissemination of your research work

Submit your manuscript at: http://papersubmission.scirp.org/ 